\title{
IN VITRO EVALUATION OF ANTIOXIDANT-MEDIATED APOPTOSIS ON CANCER CELLS AND NON-TOXICITY OF ETHANOLIC EXTRACT OF TERMINALIA CHEBULA RETZ AND PYROGALLOL
}

\author{
DEENA PRISCILLA H, JASMINE R*
}

Department of Biotechnology, Bishop Heber College, Tiruchirappalli - 620 017, Tamil Nadu, India. Email: jasminebhc@gmail.com

Received: 23 July 2018, Revised and Accepted: 17 October 2018

ABSTRACT

objective: Antioxidants are very important for human health, and hence, external supplementation is recommended to protect cells from the deleterious effects of excessive reactive oxygen species conditions that are capable of causing direct damage to deoxyribonuclieic acid (DNA) which might lead to the cause of cancer. In our research work, we have aimed to evaluate the antioxidant potential of Terminalia chebula and pyrogallol to relate to its apoptotic nature as well as prove its non-toxicity.

Methods: Investigations were carried out to determine the antioxidant activity by 2,2-diphenyl-1-picrylhydrazyl and lipid peroxidation inhibition assay of the ethanolic extract of T. chebula and pyrogallol. The apoptotic nature of tumor cells was determined by comet assay. To prove the nontoxicity of the extract as well as compound, the hemolysis assay was carried out.

Results: The results of our study established the antioxidant potential of the plant which may serve as additional evidence for the antiproliferative activity of the plant. It is considered safe for human use.

Conclusion: Plant-based traditional medicine system continues to play an essential role in health care. The ethanolic extract of T. chebula and pyrogallol possesses antioxidant and anticancer properties.

Keywords: Terminalia chebula, Antioxidant, Apoptosis, Hemolysis.

(C) 2019 The Authors. Published by Innovare Academic Sciences Pvt Ltd. This is an open access article under the CC BY license (http://creativecommons. org/licenses/by/4. 0/) DOI: http://dx.doi.org/10.22159/ajpcr.2019.v12i1.28667

\section{INTRODUCTION}

Terminalia chebula (Combretaceae), also known as the "king of medicine," seems to hold the prime place at the beginning of the list in the "Ayurvedic Materia Medica" because of its incredible power of healing. The fruit possesses numerous health benefits that may be attributed to the presence of various phytochemicals such as terpenes, alkaloids, anthocyanins, flavonoids, anthocyanins polyphenols, alkaloids, and glycosides [1]. The use of natural substances to inhibit carcinogenesis is a rapid and currently evolving aspect of research [2].

Several research reports are suggestive of the fact that the anticancer activity of medicinal plants may be due to the presence of antioxidants in them [3]. Antioxidants are very important for human health, and antioxidant supplementation is essential to provide cellular protection from the deleterious effect of excessive reactive oxygen species (ROS) concentration [4].

Production of free radicals owing to environmental pollution, harmful ultraviolet rays, and hazardous toxic chemicals poses a threat to our body causing diseases such as cancer, arthritis, diabetes, skin disorders, cataract, and age-related disease in human beings. To protect the cells from damage due to ROS, we require an antioxidant that functions interactively and synergistically to neutralize the free radicals. Chemicals present in natural products like plants might be an age-old science, but it is keeping pace with enormous potential in the current century. One of the important plants that hold good for such medication in Ayurveda is T. chebula which is rich in tannins, gallic acid, ellagic acid, and other essential compounds [5].

\section{METHODS}

Plant extract preparation

The dried fruits of $T$. chebula Retz were collected from Pachamalai Hills and authenticated (HDP 001) by Rapinat Herbarium, St. Josephs
College, Tiruchirappalli. It was crushed, powdered, and extracted with 95\% ethanol, using Soxhlet apparatus. After the completion of extraction, the extract was filtered and the solvent was removed by distillation under reduced pressure [6]

\section{2,2-diphenyl-1-picrylhydrazyl (DPPH) radical scavenging assay} The DPPH radical scavenging assay was used to analyze the antioxidant property of the given samples. Different concentrations of the samples $(100 \mu \mathrm{l})$ were added to $0.9 \mathrm{ml}$ of the methanolic solution of DPPH $(2.5 \mathrm{mg} / 100 \mathrm{ml})$, and the reactants were incubated at room temperature for $30 \mathrm{~min}$ in the dark. Different concentrations of butylated hydroxytoluene (BHT) were used as a standard, and the solvent (distilled water) was used instead of extract in control. After $30 \mathrm{~min}$, the absorbance was measured at $515 \mathrm{~nm}$ using a spectrophotometer, and the radical scavenging activity of the extract was calculated and expressed on a percentage basis [7].

\section{Lipid peroxidation inhibition potential}

Lipid peroxidation inhibition potential of the given samples was investigated in goat brain homogenate model. Goat brain was collected from freshly sacrificed animal in a local slaughterhouse and kept in phosphate-buffered saline (PBS) under cold condition until analysis. Tissue was cut using a sterile blade and weighed $500 \mathrm{mg}$ and then homogenized with $5 \mathrm{ml}$ PBS buffer ( $\mathrm{pH} 7.0)$. The brain homogenate $(0.3 \mathrm{ml})$ was preincubated with $0.3 \mathrm{ml}$ of plant extract $(1 \mathrm{mg} / \mathrm{ml})$, and then $0.1 \mathrm{ml}$ of $3 \% \mathrm{H}_{2} \mathrm{O}_{2}$ was added and incubated at $37^{\circ} \mathrm{C}$ for $10 \mathrm{~min}$. BHT $(1 \mathrm{mg} / \mathrm{ml}$ ) was used as positive control, while $0.3 \mathrm{ml}$ of PBS was used instead of extract in control. The reaction was stopped by adding $1.5 \mathrm{ml}$ of thiobarbituric acid (TBA) reagent $(0.375 \mathrm{~g}$ of TBA dissolved in $10 \%$ trichloroacetic acid [TCA]). The contents were then heated at $80^{\circ} \mathrm{C}$ for $20 \mathrm{~min}$, cooled down to room temperature, and centrifuged at $3000 \mathrm{rpm}$ for $10 \mathrm{~min}$. The absorbance of the supernatant was measured at $530 \mathrm{~nm}$, and based on the OD value, the malondialdehyde (MDA) level and lipid peroxidation inhibition capacity of the sample were calculated [8]. 


\section{Comet assay}

Briefly, michigan cancer cell foundation (MCF-7) cells were seeded in a six-well plate at a density of 10,000 cells/well and incubated for 24 at $37^{\circ} \mathrm{C}$ in a humidified $5 \% \mathrm{CO}_{2}$ incubator. The wells were washed with sterile PBS and treated with $384.5 \mu \mathrm{g} / \mathrm{ml}$ of the ethanolic extract of $T$. chebula and $83.5 \mu \mathrm{g} / \mathrm{ml}$ of pyrogallol (based on half maximal inhibitory concentration [IC50] dose) in a serum-free dulbecco's minimal essential media (DMEM) medium and incubated for $24 \mathrm{~h}$ at $37^{\circ} \mathrm{C}$ in a humidified $5 \% \mathrm{CO}_{2}$ incubator. The cells were harvested by trypsinization in a $1.5 \mathrm{ml}$ tube, and comet assay was performed based on the protocol of Nandha kumar et al. with slight modifications. The microscopic slides were sequentially coated with $200 \mu \mathrm{L} 0.75 \%$ normal melting agarose as the first layer and $100 \mu \mathrm{L}$ of $0.5 \%$ low melting agarose as the second layer. The next step was to add $20 \mu \mathrm{L}$ cell suspensions to $60 \mu \mathrm{L}$ of $0.5 \%$ low melting agarose, which was distributed on the slides as the third layer. Then, the slides were incubated in cell lysis buffer for overnight at $4^{\circ} \mathrm{C}$. After that, the slides were immersed in double-distilled water for 3 times followed by incubation in unwinding solution for $20 \mathrm{~min}$. The slides were placed in a horizontal gel electrophoresis tank containing electrophoresis solution. The electrophoresis was conducted at $25 \mathrm{~V}$ for $25 \mathrm{~min}$. Then, the slides were incubated in neutralization buffer for $10 \mathrm{~min}$ followed by immersion in double-distilled water thrice and air-dried. The cells were stained with ethidium bromide and observed under a fluorescent microscope. All steps were carried out under dim light to minimize extra DNA damage [9].

\section{Determination of cellular toxicity using sheep erythrocytes (hemolysis)}

Briefly, 10-fold serial dilutions of the extract and pyrogallol were made in PBS. A total volume of $0.8 \mathrm{ml}$ for each dilution was placed in an Eppendorf tube. A negative control (saline only) and a positive control (standard, $5 \mathrm{mg} / \mathrm{ml}$ ) were also included in the analysis. Fresh sheep erythrocytes were added to each tube, to make up a final volume of $1 \mathrm{ml}$. Solutions were incubated at $37^{\circ} \mathrm{C}$ for $30 \mathrm{~min}$, and all tubes were centrifuged for $5 \mathrm{~min}$ and then observed for hemolysis. Complete hemolysis was indicated by a clear red solution without any deposit of erythrocytes [10]

\section{RESULTS}

Preparation of ethanolic extract

$500 \mathrm{~g}$ of fruit powder of T. chebula yielded $12.25 \% \mathrm{w} / \mathrm{w}$ of crude ethanolic extract. The greenish-black colored residue was obtained.

\section{Pyrogallol - as the promising bioactive compound}

Based on the results of the gas chromatography-mass spectrometry analysis, pyrogallol was reported to be the predominant compound having a peak area of $82.7 \%$ at the retention time (RT) 22.41 [11]. Hence, further work on the compound was carried out using commercially available pyrogallol to serve as an additional evidence for the experimental findings.

\section{Free radical scavenging activity by DPPH method}

The DPPH radical scavenging ability of the crude ethanolic extract of the fruit of T. chebula at different concentrations $(100,200,300,400$, and $500 \mu \mathrm{g} / \mathrm{ml}$ ) was compared with the reference standard ascorbic acid. The activity of the extract was found to be dose dependent. The percentage of antioxidant activity of extract from low to high dose was $18 \%, 22 \%$, $47 \%$, and $50 \%$ with inhibition percentage being maximum at dosage $500 \mu \mathrm{g} / \mathrm{ml}$ which recorded $77 \%$ while that of ascorbic acid is $95 \%$ at the same concentration. The antioxidant property of DPPH radical scavenging ability is due to its hydrogen-donating ability. Standard ascorbic acid exhibited $86.6 \%, 90 \%, 91.6 \%, 95 \%$, and $98.3 \%$ of antioxidant activity at concentrations of $100,200,300,400$, and $500 \mu \mathrm{g} / \mathrm{ml}$, respectively. The percentage of antioxidant activity of pyrogallol was reported as $38 \%$, $51 \%, 64 \%, 75 \%$, and $84 \%$, respectively (Table 1).

\section{Lipid peroxidation inhibition potential}

Lipid peroxidation inhibition potential was performed in goat brain homogenate model. Normal brain homogenate served as blank.
Table 1: Free radical scavenging activity of ethanolic extract of T. chebula and pyrogallol by DPPH method

\begin{tabular}{llllll}
\hline Concentration in $\boldsymbol{\mu g} / \mathbf{m l}$ & $\mathbf{1 0 0}$ & $\mathbf{2 0 0}$ & $\mathbf{3 0 0}$ & $\mathbf{4 0 0}$ & $\mathbf{5 0 0}$ \\
\hline $\begin{array}{l}\text { \% of antioxidant activity for ethanolic } \\
\text { extract }\end{array}$ & 18 & 22 & 47 & 50 & 77 \\
$\begin{array}{l}\% \text { of antioxidant activity for } \\
\text { pyrogallol } \\
\% \text { of antioxidant activity for ascorbic }\end{array}$ & 38 & 51 & 64 & 75 & 84 \\
acid
\end{tabular}

T. chebula: Terminalia chebula, DPPH: 2,2-diphenyl-1-picrylhydrazyl

Untreated brain tissue homogenate served as negative control. Brain tissue homogenate treated with BHT $(1 \mathrm{mg} / \mathrm{ml}$ ) served as positive control. The crude ethanolic extract and pyrogallol-treated brain tissue homogenates were prepared at a concentration of $1 \mathrm{mg} / \mathrm{ml}$. Based on the MDA content (nM/100 g of tissue), the percentage of lipid peroxidation inhibition was calibrated.

The standard BHT-treated tissue exhibited $69.47 \%$ of lipid peroxidation inhibition, whereas crude extract showed $59.68 \%$ and pyrogallol showed $50.88 \%$ of inhibition (Fig. 1).

\section{Comet assay}

DNA from MCF-7 cells treated with ethanolic extract of T. chebula (334.54 $\mu \mathrm{g} / \mathrm{ml})$, pyrogallol $(83.59 \mu \mathrm{g} / \mathrm{ml})$, and untreated control cells was electrophoresed and observed for comet-like appearance. The extent of DNA damage was directly proportional to the length of the tail developed. The extent of DNA damage in pyrogallol-treated cells was more when compared to ethanolic extract (Fig. 2a-c).

\section{Hemolysis}

The absence of hemolysis of erythrocytes indicted the safe and nontoxic nature of the ethanolic extract and pyrogallol (Fig. 3).

\section{DISCUSSION}

The ethanolic extract of $T$. chebula Retz was found to possess different phytochemicals such as alkaloid, flavonoid, phenolic compounds, and tannins which were also in accordance with other reports [12-19]. Polyphenols are derivatives of plant products that are present abundantly in fruits and plants. They possess antioxidant activity and are capable of scavenging free radicals. In the research carried out in Thailand, to determine the antibacterial activity of pyrogallol against Vibrio parahaemolyticus (known for its toxicity against human and marine animals), the susceptibility was found to be $32-64 \mathrm{mg} / \mathrm{ml}$ for both MIC and minimum bactericidal concentration. This was the first study reported for pyrogallol against bacteria in aquaculture [20]. The highperformance liquid chromatogram depicting the phenolic profiling in the Iranian rice straw varieties showed gallic acid, pyrogallol, and caffeic acid as the predominant compound. The results suggest the possible application of these compounds in the medical and food industries [21].

Polyphenols obtained from Mango (Mangifera indica Linn.) and the absorbable microbial metabolite pyrogallol from non-absorbable gallotannins seem to promote antiproliferative activity on breast cancer. The in vitro studies carried out at relevant concentrations suitable for maintaining balanced physiological activity have been attributed to these polyphenols [22].

Free radicals impose the deleterious effects on living cells affecting the biomolecules and biological system. An increased activity of antioxidant enzymes was observed. Enzyme activity was restored in diseased condition on the administration of the plant extracts as reported earlier in other plants [23-25].

Breast cancer is potentially a life-threatening malignancy in women. Cancer leads to oxidative stress which increases with disease progression. Hence, studies on antioxidants may be promising areas of research 


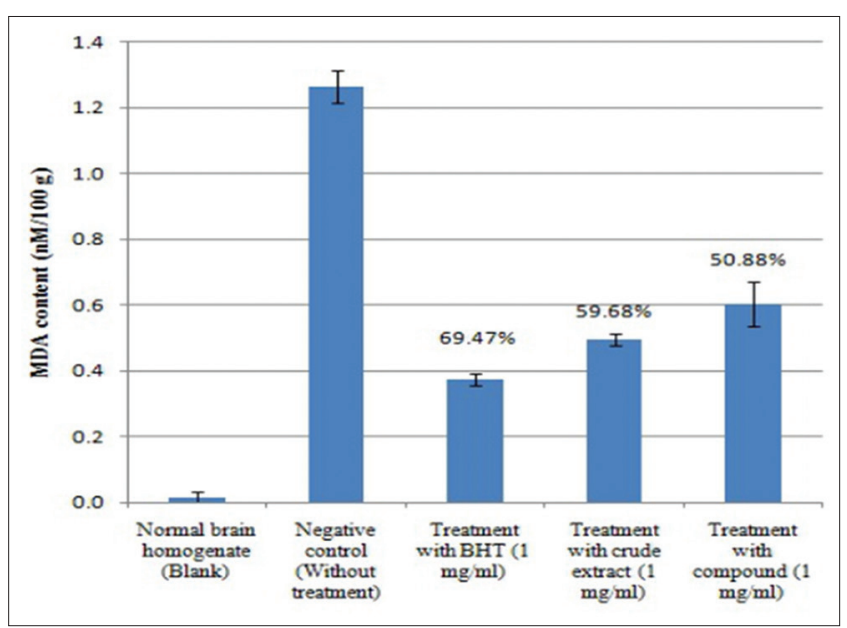

Fig. 1: Lipid peroxidation inhibition potential of ethanolic extract and pyrogallol. Values are mean \pm standard deviation of duplicate analysis

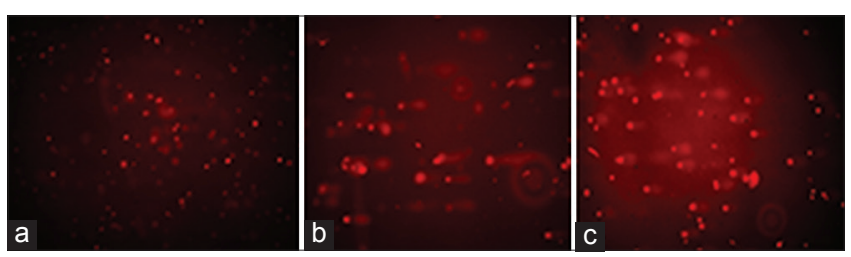

Fig. 2: (a-c) Effect of the ethanolic extract of T. chebula and pyrogallol on MCF-7cells analyzed using comet assay

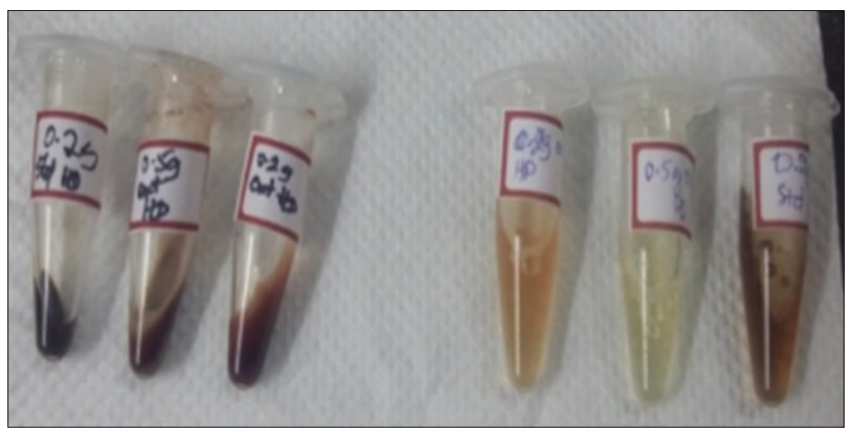

Fig. 3: Absence of hemolysis

for this clinical menace [26-29]. Different antioxidant assays such as 2,2'-azinobis-(3-ethylbenzothiazoline-6-sulfonate) (ABTS), DPPH, $\mathrm{H}_{2} \mathrm{O}_{2}$, superoxide, reducing power, and in vivo assays of antioxidants enzymes from the liver of experimental mice are done to determine the presence as well as the level of antioxidants available in the biological sample. Phenolic compounds have become a cause of concern in traditional medicine due to their antioxidant nature that is being looked on with hope for the treatment and prevention of cancer [30,31]. It has been reported that the three extracts of T. chebula (aqueous, methanol, and $95 \%$ ethanol) are the richest source of phenolic compounds [32].

IC50 values of $T$. chebula extract and pyrogallol were $334.54 \mu \mathrm{g} / \mathrm{ml}$ and $83.59 \mu \mathrm{g} / \mathrm{ml}$, respectively. Our results were in accordance to previous reports on Dillenia suffruticosa by Yin Sim Tor [33]. The acute oral toxicity study carried out by Bag et al. [34] using the ethanolic extract of T. chebula Retz in mice at concentration 100, 250, 500, 1000, 2000, and $4000 \mathrm{mg} / \mathrm{kg}$ showed no observable changes associated with toxicity proving the effectiveness of the extracts to be therapeutically safe. The lethal concentration $50 \%$ value was determined as more than $4 \mathrm{~g} / \mathrm{kg}$. In our study also, no hemolysis of red blood cells was observed. This indicates the treatment of plant products and its derivatives to be safe and non-toxic at permissible levels. Thus, herbal lead molecules seem to possess antitumor activity by the induction of apoptosis [35].

\section{CONCLUSION}

The ethanolic extract and pyrogallol harbor the adequate efficacy to scavenge the free radicals generated as a result of oxidative stress confirming the antioxidant nature. It is capable of inducing DNA damage leading to apoptosis of tumor cells. These are safe and non-toxic based on toxicity studies at the recommended doses.

\section{AUTHORS' CONTRIBUTION}

Dr. R. Jasmine - Provided the idea and carried out the correction of the manuscript. Deena Priscilla - Executed the research work and prepared the manuscript.

\section{CONFLICTS OF INTEREST}

The authors declare no conflicts of interest.

\section{REFERENCES}

1. Bag A, Bhattacharyya SK, Chattopadhyay RR. The development of Terminalia chebula Retz. (Combretaceae) in clinical research. Asian Pac J Trop Biomed 2013;3:244-52.

2. Gacche RN, Shaikh RU, Pund MM. In vitro evaluation of anticancer and antimicrobial activity of selected medicinal plants from Ayurveda. Asian J Trad Med 2011;6:1-7.

3. Umadevi M, Kumar KP, Bhowmik D, Duraivel S. Traditionally used anticancer herbs in India. J Med Plants Stud 2013;1:56-74.

4. Chen C, Chen Y, Lu P, Lin W, Chen T, Lin C. Proteus mirabilis urinary tract infection and bacteremia: Risk factors, clinical presentation, and outcomes. J Microbiol Immunol Infect 2012;45:228-36.

5. Walia H, Arora S. Terminalia chebula - A pharmacognostic account. J Med Plants Res 2013;7:1351-61.

6. Mukherjee PK. Quality Control of Herbal Drugs: An Approach to the Evaluation of Botanicals. New Delhi: Business Horizons; 2002.

7. Sánchezmoreno C, Larrauri JA, Saura-Calixto F. A procedure to measure the antiradical efficiency of polyphenols. J Sci Food Agric 1998;76:270-6.

8. Botsoglou NA, Fletouris DJ, Papageorgiou GE, Vassilopoulos VN, Mantis AJ, Trakatellis AG. Rapid, sensitive, and specific thiobarbituric acid method for measuring lipid peroxidation in animal tissue, food, and feedstuff samples. J Agric Food Chem 1994;42:1931-7.

9. Nandhakumar S, Parasuraman S, Shanmugam M, Rao K, Chand P, Bhat B. Evaluation of DNA damage using single-cell gel electrophoresis (Comet Assay). J Pharmacol Pharmacother 2011;2:107.

10. Xianngou H, Ursula M. Antifungal compound from Solanum nigrescens. J Ethano Pharmacol 1994;43:173-7.

11. Priscilla HD, Jasmine R. Evaluation of in vitro anticancer activity of Terminalia chebula and identification of phytocompounds by GC-MS analysis. J Chem Pharm Res 2016;8:683-8.

12. Baliah NT, Astalakshmi A. Phytochemical analysis and antibacterial activity of extracts from Terminalia chebula Retz. Int J Curr Microbiol Appl Sci 2014;3:992-9.

13. Guleria S, Dev K, Khosla PK. Comparative analysis of phytochemicals and antioxidant activities of fruit and leaves of Terminalia chebula from Himachal Pradesh. Int J Biol Pharm Allied Sci 2016;5:1195-206.

14. Subha SS, Divakar KM. GC-MS analysis of the phytoconstiutents of methanolic fruit extracts of Terminalia chebula Retz. Int J Innov Pharm Sci Res 2016;4:53-61.

15. Akmal NL, Gayathri R, Priya VV. Phytochemical screening and in vitro free radical scavenging of Terminalia chebula. Int J Pharm Sci Rev Res 2016;39:226-31.

16. Tariq AL, Riyaz AL. Significance and importance of phytochemicals present in T. chebula. Int J Drug Res 2013;5:256-62.

17. Ram J, Moteriya P, Chanda S. Phytochemical screening and reported biological activities of some medicinal plants of Gujarat region. J Pharmacogn Phytochem 2015;41:92-198.

18. Devi PN, Kaleeswari S, Poonkothai M. Antimicrobial activity and phytochemical analysis of fruit extracts of Terminalia bellerica. Int J Pharm Pharm Sci 2014;6:639-42.

19. Manohar VR, Chandrashekar R, Rao SN. Phytochemical analysis of Terminalia belerica fruit pulp extracts. World J Pharm Pharm Sci 2012;1:1376-83. 
20. Tinh TH, Nuidate T, Vuddhakul V, Rodkhum C. Antibacterial activity of pyrogallol, a polyphenol compound against Vibrio parahaemolyticus isolated from the central region of Thailand. Proc Chem 2016;18:162-8.

21. Karimi E, Mehrabanjoubani P, Keshavarzian M, Oskoueian E, Jaafar HZ, Abdolzadeh A. Identification and quantification of phenolic and flavonoid components in straw and seed husk of some rice varieties (Oryza sativa L.) and their antioxidant properties. J Sci Food Agric 2014;94:2324-30.

22. Nemec MJ, Kim H, Marciante AB, Barnes RC, Talcott ST, Talcott SU. Pyrogallol, an absorbable microbial gallotannins-metabolite and mango polyphenols (Mangifera indica $\mathrm{L}$.) suppress breast cancer ductal carcinoma in situ proliferation in vitro. Food Function 2016;7:3825-33.

23. Haritha K, Ramesh B, Saralakumari D. Effect of Aloe vera gel on antioxidant enzymes in streptozotocin-induced cataractogenesis in male and female Wistar rats. J Acute Med 2014;4:38-44.

24. Chioma OO, Victor OG, Emeka AG. Ethanol extracts of Piper nigrum ameliorate serum lipid peroxidation and antioxidant enzyme activities in diabetic rats. World Appl Sci J 2014;32:27-33.

25. Hefnawy T, Ali O. Assessment of antioxidant capacity of ethanolic extract of Portula caoleracea leaves in vitro and in vivo. J Med Plants Res 2015;9:335-42.

26. Piluzza G, Bullitta S. Correlations between phenolic content and antioxidant properties in twenty-four plant species of traditional ethnoveterinary use in the Mediterranean area. Pharm Biol 2011:49:240-7.

27. Govindan P, Muthukrishnan S. Evaluation of total phenolic content and free radical scavenging activity of Boerhavia erecta. J Acute Med 2013;3:103-9.
28. Lobo V, Patil A, Phatak A, Chandra N. Free radicals, antioxidants and functional foods: Impact on human health. Pharmacogn Rev 2010;4:118.

29. Vijaya Bharathi S, Anuradha V, Rubalakshmi G. In vitro antioxidant and antimicrobial activity of Phoenix pusilla root extract. Asian J Pharm Clin Res 2018; 11:194-7.

30. Loganayaki N, Siddhuraju P, Manian S. Antioxidant activity and free radical scavenging capacity of phenolic extracts from Helicteres isora L. and Ceiba pentandra L. J Food Sci Technol 2011;50:687-95.

31. Fattahi S, Zabihi E, Abedian Z, Pourbagher R, Ardekani AM, Mostafazadeh A, et al. Total phenolic and flavonoid contents of aqueous extract of stinging nettle and in vitro antiproliferative effect on Hela and BT-474 cell lines. Int J Mol Cell Med 2014;3:102-7.

32. Chang CL, Lin CS. Phytochemical composition, antioxidant activity, and neuroprotective effect of Terminalia chebula Retzius extracts. Evid Based Complementary Altern Med 2012;2012:1-7.

33. Tor YS, Yazan LS, Foo JB, Armania N, Cheah YK, Abdullah R, et al. Induction of apoptosis through oxidative stress-related pathways in MCF-7, human breast cancer cells, by ethyl acetate extract of Dillenia suffruticosa. BMC Complementary Altern Med 2014;14:55.

34. Bag A, Bhattacharyya SK, Pal NK, Chattopadhyay RR. In vitro antimicrobial potential of Terminalia chebula fruit extracts against multidrug-resistant uropathogens. Asian Pac J Trop Biomed 2012;2:597-1

35. Sharma S, Kumar V. In vitro cytotoxicity effect on MCF-7 cell line of co-encapsulated artesunate and curcumin liposome. Int J Pharm Pharm Sci 2017;9:123-8. 